\title{
Isothermal and Kinetic Studies of Biosorption of Low Concentration Cr(III) from Aqueous Solution by 4 Microbial Biosorbents
}

\author{
Rui Wang ${ }^{1,2,3}$, Ming Zhong ${ }^{4}$, Wei $\mathrm{Li}^{4}$, Yangwu Chen ${ }^{2,3}$, \\ Zhouliang Tan ${ }^{2,3}$, Xin Li ${ }^{2,3 *}$, Jianqiang Zhang ${ }^{1}$ \\ ${ }^{1}$ Faculty of Geosciences and Environmental Engineering, Southwest Jiaotong University, 611756 Chengdu, China \\ ${ }^{2}$ Key Laboratory of Environmental and Applied Microbiology, Chengdu Institute of Biology, \\ Chinese Academy of Sciences, 610041 Chengdu, China \\ ${ }^{3}$ Environmental Microbiology Key Laboratory of Sichuan Province, Chengdu Institute of Biology, \\ Chinese Academy of Sciences, 610041 Chengdu, China \\ ${ }^{4}$ Haitian Water Group Co. Ltd, 610095 Chengdu, China
}

Received: 7 May 2021

Accepted: 9 September 2021

\begin{abstract}
This study investigated the biosorption characteristics of low concentration $\mathrm{Cr}$ (III) by four biosorbents of microbial powders (TP, XB, MY and TQ). All biosorbents showed promising sorption efficiency towards Cr(III). The results of SEM and FTIR showed that the gaps of the adsorbent surface were filled, and the groups of hydroxyl, carboxyl, polyglucose, amine, phosphoric acid, and sulfur functional groups played an important role. The equilibrium adsorption capacity of TP, XB, MY, and TQ were achieved by $6.92,10.35,9.20$ and $8.72 \mathrm{mg} / \mathrm{g}$, respectively. The data of isotherm models (Langmuir, Freundlich, Temkin and Dubimim-Radushkevich isotherm models) revealed that TP, MY and TQ were fitted well with the Langmuir model which means the adsorption functional group or activity site on the surface was monolayer; XB was fitted well with Temkin model which means that the surface coverage of adsorbent increased while the adsorption heat decreased linearly. The Lagergren model and intraparticle diffusion model were used to present the kinetic process, the results showed that the biosorption process for all the studied adsorbent followed three phases: rapid phase, slow phase, and equilibrium. The first phase was the rate-controlling one. Moreover, the four biosorbents were regenerated by desorption and still had adsorption performance after four times of reuse. We proved that the four biosorbents can be feasible biomass for the removal of low concentration Cr(III) from aqueous solutions.
\end{abstract}

Keywords: biosorption, $\mathrm{Cr}(\mathrm{III})$, isotherm models, kinetics

e-mail: lixin@cib.ac.cn 


\section{Introduction}

Chromium (Cr) compounds are widely used by various industries such as leather tanning, electroplating, metal finishing, paint and pigments, resulting in a large quantity of $\mathrm{Cr}$ being discharged into the environment through industrial wastewaters $[1,2]$. China is becoming one of the leather processing centers and the $\mathrm{Cr}$ emissions are increasing annually. $\mathrm{Cr}$ is considered as an essential nutrient required for sugar and fat metabolism in organisms [2], but it is nondegradable in the environment and participates in the food chain cycle This lead to the biomagnification of $\mathrm{Cr}$ in the ecosystems, posing significant threats to environmental safety and increasing human diseases (e.g. skin allergic, cancer) [3,4]. $\mathrm{Cr}(\mathrm{III})$ is a most often identified form of $\mathrm{Cr}$ that presents in wastewaters, possessing strong toxicity. In addition, $\mathrm{Cr}(\mathrm{III})$ may be oxidized to $\mathrm{Cr}(\mathrm{VI})$ by environmental oxidants [5], while the EPA stated that the most toxic and carcinogenic chromium is $\mathrm{Cr}(\mathrm{VI})$, and great concern has been posed in terms of its immune toxicity, neurotoxicity, reproductive toxicity, genotoxicity, and carcinogenicity towards human health [6].

Common methods of wastewater treatment to $\mathrm{Cr}$ (III) include chemical precipitation, electric deposition, ion exchange, activated carbon adsorption method etc. [7-12]. However, some methods are inefficient when treating effluent with low concentration of $\mathrm{Cr}$, limited by drawbacks such as complex operation, high operating cost and energy consumption, and the secondary pollution [13]. Thus, the use of new low-cost materials that are able to replace these materials is of great importance. Biosorption is considered as an appropriate method for treating heavy metal wastewater, especially for the low concentration wastewater. It is effective to remove specific metal ions in wastewater of low or moderate concentrations.at relatively wide $\mathrm{pH}$ and temperature conditions. Besides, biosorption requires less investment and lower operating cost, but has higher metal removal efficiency with no secondary pollutants produced. These facts substantially improves the application potential of biosorption in regard to heavy metal depletion [14], and therefore attracts attention broadly. The removal of $\mathrm{Cr}$ by biosorption was also reported [15-17], however, the main focuses were only on $\mathrm{Cr}(\mathrm{IV})$ whereas $\mathrm{Cr}(\mathrm{III})$ is overlooked. On the other hand, unlike the industrial sewage, a real environment often harbors low concentration of $\mathrm{Cr}$ (III) which may limit the performance of biosorbents. Thus, it is of great significance to develop more efficient $\mathrm{Cr}$ (III) removal biosorbents, aiming at low-concentration $\mathrm{Cr}$ (III) systems.

In this study, four microbes were obtained from leather factory sewage sludge and cultured with $\mathrm{Cr}$ (III)containing media, and were used for the biosorption tests towards $\mathrm{Cr}(\mathrm{III})$. The factors that influence biosorption of four microbes towards of $\mathrm{Cr}(\mathrm{III})$, including $\mathrm{pH}$, biosorbent dosage, initial $\mathrm{Cr}(\mathrm{III})$ concentration, acid or alkaline pretreatment and temperature were examined in our previous work. The results showed that four biosorbents were efficient to adsorb $\mathrm{Cr}(\mathrm{III})$ in a $5.0 \mathrm{mg} / \mathrm{L}$ solution [18]. In this paper, we aim to deeply explore adsorption characteristics of low concentration $\mathrm{Cr}(\mathrm{III})$ solution by investigating surface feature and kinetic modeling and isotherm studies of four microbial adsorbents.

\section{Material and Methods}

\section{Biomass and Preparation}

Four microbial strains were isolated from leather factory sewage sludge, and were passaged with beef extract-peptone medium under increasing concentrations of $\mathrm{Cr}_{2}\left(\mathrm{SO}_{4}\right)_{3}\left(1.0 \sim 10 \mathrm{mg} \mathrm{L}^{-1}\right)$. They were named as TP, $\mathrm{XB}, \mathrm{MY}$ and TQ respectively, and are identified as Trichosporonales sp. (TP), Bacillus cereus (XB, MY) and Aspergillus terreus (TQ), respectively, by the $16 \mathrm{~S}$ rRNA and $18 \mathrm{~S}$ rRNA sequencing analysis. After $72 \mathrm{~h}$, cultured biomass was collected by repeated centrifugation (4800 rpm, $25 \mathrm{~min}$ ) and washed with deionized water until clear supernatant appears. Parts of wet samples were used to screen biosorbent, and the rest were dried at $55^{\circ} \mathrm{C}$ for $48 \mathrm{~h}$. Dried microbial biomass was ground and sieved to different sizes, whereas $100-150 \mu \mathrm{m}$ fraction was used in adsorption experiment.

\section{Reagents and Equipment}

All chemicals used in this experiment were at analytical grade. The solvent used in all experiments was double deionized water, SZ-93A (Shanghai YaRong). The concentrated solution of $\mathrm{Cr}(\mathrm{III})$ was prepared in $100 \mathrm{ml}$ volumetric flask by dissolving appropriate amount of $\mathrm{Cr}_{2}\left(\mathrm{SO}_{4}\right)_{3}$ and was stocked at $4^{\circ} \mathrm{C}$. In order to avoid sedimentation, sulfuric acid was added into the solution. The $\mathrm{pH}$ values of aqueous phase were measured by a $\mathrm{pH}$ meter, PHS-3C (INESA INSTRUMENT). The experimental solution was diluted by double deionized water.

The dry biomass of four biosorbents were added into $\mathrm{Cr}$ (III) solution $(10.0 \mathrm{mg} / \mathrm{L})$ for $6 \mathrm{~h}$, then were gathered by centrifuge tube and dried after centrifugation. The samples were spread evenly on glass slides and sputter coated with gold. Specimens were observed using a HITACHI SU8020 Scanning Electron Microscope equipped with an Energy Dispersive X-ray spectrophotometer (EDX) and HITACHI MC1000 ion sputter device. Moreover, the control samples and biosorbents were ground to powder using an agate mortar with spectroscopic quality $\mathrm{KBr}$. Fourier Transform InfraRed (FTIR) spectra was recorded by Bruker IFS66V/S FTIR spectrometer in the region of $500-4000 \mathrm{~cm}^{-1}$. All operating parameters were set as introductory by manufacturer. 


\section{Batch Biosorption Procedure}

Our previous work revealed that the optimal $\mathrm{pH}$ value, mass concentration and temperature of biosorption were $4.0,0.5 \mathrm{~g} / \mathrm{L}$ and 30 , respectively, while the optimum adsorption efficiency of TP, XB, MY and TQ is $75.89 \%, 80.83 \%, 74.11 \%$ and $74.31 \%$, respectively [11]. These conditions were set up in this study for further isothermal and dynamic experiments.

$0.5 \mathrm{~g} / \mathrm{L}$ biomass dosage was adopted in the $150 \mathrm{ml}$ stoppered conical flask, and then the flasks were conducted in a constant temperature shaker bath at $20-50^{\circ} \mathrm{C}(60 \mathrm{rpm})$ to ensure sufficient mixing of biosorbent and solution. The contact time was set up from 0.25 to $12 \mathrm{~h}$ throughout the study. Solutions with different concentration of $\mathrm{Cr}(\mathrm{III})$ was $2.0,4.0,6.0,8.0$ and $10.0 \mathrm{mg} / \mathrm{L}$ in biosorption isotherm experiment. They were prepared from stock $100 \mathrm{mg} / \mathrm{L} \mathrm{Cr}(\mathrm{III})$ standard. After centrifugation and filtration (filtered through filter paper), the $\mathrm{Cr}$ (III) concentrations in the supernatant were detected by the lame atomic absorption spectrophotometer.

After the adsorption, the biosorbents were gathered and washed with distilled water three times, and then the desorption (elution) of the adsorbents were carried out with $0.5 \mathrm{~mol} / \mathrm{L}$ hydrochloric acid solution as the desorbent, and the samples were taken every $2 \mathrm{~min}$ within $0.5 \mathrm{~h}$, every $5 \mathrm{~min}$ after $0.5 \mathrm{~h}$, and every $10 \mathrm{~min}$ after $1 \mathrm{~h}$. After collecting the samples, the $\mathrm{Cr}(\mathrm{III})$ concentration in the desorbed solution was determined and analyzed, which the kinetic curves of desorption were analyzed [19]. The reused biosorbents were washed with double-distilled water until the filtrate was neutral, then re-dried and the adsorption rate $(\mathrm{Q})$ was measured under the same adsorption conditions. The above adsorption and regeneration steps were repeated several times to investigate the effect of regeneration times on the adsorption efficiency of the biosorbents.

\section{Measurement of Heavy Metal Sorption and Desorption}

The amount of $\mathrm{Cr}(\mathrm{III})$ adsorbed by biosorbents was calculated as follows [20]:

$$
Q \%=100 *\left(C_{0}-\mathrm{C}\right) / C_{0}
$$

...where, Q represents percentage biosorption of $\mathrm{Cr}(\mathrm{III})$ ion, $\mathrm{C}_{0}$ represents initial and final metal ion concentration $(\mathrm{mg} / \mathrm{L})$, and $\mathrm{C}$ represents final metal ion concentration $(\mathrm{mg} / \mathrm{L})$.

$$
\mathrm{q}=\mathrm{V}\left(\mathrm{C}_{0}-\mathrm{C}\right) / \mathrm{M}
$$

...where, q represents adsorption capacity in $\mathrm{mg}$ of metal per $\mathrm{g}$ of biosorption $(\mathrm{mg} / \mathrm{g}), \mathrm{V}$ represents volume of the liquid (L), and $\mathrm{M}$ represents weight of the biosorption (g).
The amount of $\mathrm{Cr}(\mathrm{III})$ desorbed by biosorbents was calculated as follows

$$
D Q \%=100 * \mathrm{C} / C_{0}
$$

...where, DQ represents percentage desorption of Cr(III) ion in the solution.

\section{Isotherm Models}

Biosorption isotherms are important for describing the equilibrium status between solid adsorbent and metal ions in the aqueous solution. It also provides essential information and correlation parameters about maximum adsorption capacity and kinetics, as well as thermodynamics to realize the mechanism of biosorption in depth. Langmuir, Freundlich, Temkin and Dubimim-Radushkevich (D-R) isotherms were used to investigate the biosorption of $\mathrm{Cr}(\mathrm{III})$.

Langmuir isotherm model:

$$
\mathrm{q}_{\mathrm{e}}=\frac{\mathrm{q}_{\mathrm{m}} \mathrm{bc} \mathrm{e}_{\mathrm{e}}}{1+\mathrm{bc} \mathrm{c}_{\mathrm{e}}}
$$

Or, in its linearized form:

$$
\frac{c_{e}}{q_{e}}=\frac{c_{e}}{q_{m}}+\frac{1}{q_{m} b}
$$

...where, $c_{e}$ represents equilibrium $\mathrm{Cr}(\mathrm{III})$ ions concentration in the solution $(\mathrm{mg} / \mathrm{g}), \mathrm{q}_{\mathrm{e}}$ represents equilibrium $\mathrm{Cr}$ (III) ions concentration on the biosorbent $(\mathrm{mg} / \mathrm{L}), \mathrm{q}_{\mathrm{m}}$ represents saturated monolayer biosorption capacity $(\mathrm{mg} / \mathrm{g})$, and $\mathrm{b}$ represents Langmuir biosorption constant $(\mathrm{mg} / \mathrm{L})$ relating to the free energy of biosorption (reflects the affinity between adsorbent and sorbate).

Freundlich isotherm model:

$$
\mathrm{q}_{\mathrm{e}}=\mathrm{Kc}_{\mathrm{e}}^{1 / \mathrm{n}}
$$

The equation can be linearised in the following natural logarithmic form:

$$
\ln q_{e}=\ln k_{\mathrm{F}}+\frac{1}{n} \ln \mathrm{C}_{e}
$$

...where, KF represents biosorption capacity constant, and $1 / \mathrm{n}$ represents adsorption intensity empirical parameter.

Temkin isotherm model:

$$
q=\frac{R T}{b} \ln (a c)=k_{1} \ln \left(k_{2} c\right)
$$

...where, $\mathrm{k} 1$ represents $\mathrm{RT} / \mathrm{b}$ is related to the adsorption heat, $\mathrm{k} 2$ represents equilibrium binding constant (mg/L) corresponding to the maximum binding energy, R represents universal gas constant $\left(\mathrm{J} / \mathrm{mol}^{\circ} \mathrm{K}^{-1}\right)$, 
$\mathrm{T}$ represents temperature $(\mathrm{K})$, and $\mathrm{b}$ represents variation of adsorption energy $(\mathrm{J} / \mathrm{mol})$.

$\mathrm{D}-\mathrm{R}$ isotherm model:

$$
\ln q=\ln q_{m}-\beta \varepsilon^{2}
$$

...where, $\varepsilon$ (Polanyi potential) represents RT $\ln \left(1+1 / \mathrm{C}_{\mathrm{e}}\right)$, qm represents maximum biosorption capacity $(\mathrm{mol} / \mathrm{g})$, $\beta$ represents activity coefficient (related to biosorption mean free energy per mole of the sorbate when it is transferred to the surface of the solid from infinity in the solution).

Free energy per mole of the sorbate, E $(\mathrm{KJ} / \mathrm{mol})$, can be computed using the following equation:

$$
E=\frac{1}{\sqrt{-2 \beta}}
$$

Kinetic model:

Sorption solid-liquid kinetics are controlled by several independent steps, which normally comprise transport phenomenon and chemical reactions. In porous media, there are four steps: i) transport of the sorbate $(\mathrm{Cr})$ in the bulk solution; ii) membrane diffusion from the bulk solution through the boundary layer of fluid, immediately attaching to the external surface of the biosorbent particle; iii) diffusion through the particle and the chemical binding reaction of the sorbate. Within such process, intraparticle diffusion or chemical binding process controls the adsorption kinetic mechanism. Two kinetic models, Lagrange and Intraparticle diffusion model, were applied to the kinetics modeling.

The pseudo-first-order Lagergren equation:

$$
\frac{\mathrm{d}_{\mathrm{qt}}}{\mathrm{dt}}=\mathrm{K}_{1}\left(\mathrm{q}_{1}-\mathrm{q}_{\mathrm{t}}\right)
$$

The linear form of the pseudo-first-order rate equation:

$$
\log \left(q_{1}-q_{t}\right)=\log \left(q_{1}\right)-\frac{K_{1}}{2.303} t
$$

...where, q1 represents the amounts of the metal ions adsorbed at equilibrium (mg/g), qt represents amounts of the metal ions adsorbed at $\mathrm{t}(\mathrm{min})(\mathrm{mg} / \mathrm{g})$, and $\mathrm{k}_{1}$ represents pseudo-first order rate constant of adsorption $\left(\min ^{-1}\right)$.

The pseudo-second-order Lagergren equation:

$$
\frac{\mathrm{d}_{\mathrm{qt}}}{\mathrm{dt}}=\mathrm{K}_{2}\left(\mathrm{q}_{2}-\mathrm{q}_{\mathrm{t}}\right)^{2}
$$

The linear form of the pseudo-second-order rate equation:

$$
\frac{t}{q_{t}}=\frac{1}{k_{2} q_{2}^{2}}+\frac{t}{q_{2}}
$$

...where, q1 represents the amounts of the metal ions sorbed at equilibrium $(\mathrm{mg} / \mathrm{g})$, qt represents amounts of the metal ions adsorbed at $\mathrm{t}(\mathrm{min})(\mathrm{mg} / \mathrm{g})$, and $\mathrm{k}_{2}$ represents pseudo-first order rate constant of adsorption $\left(\min ^{-1}\right)$.

If $\mathrm{qt} / \mathrm{t}=0$, the initial adsorption rate ho $(\mathrm{mg} / \mathrm{g}$ $\left.\min ^{-1 / 2}\right)$ :

$$
h_{0}=k_{2} q_{2}^{2}
$$

The intraparticle diffusion equation:

$$
q_{t}=K_{p} t^{1 / 2}
$$

...where, $\mathrm{kp}$ represents internal diffusion coefficient $(\mathrm{mg} / \mathrm{g} \mathrm{min}-1 / 2)$, qt represents amount of metal adsorbed at time $\mathrm{t}(\mathrm{mg} / \mathrm{g})$, and $\mathrm{t}$ represents adsorption time (min).

\section{Measurement of Heavy Metal Desorption}

Exponential decay kinetic model:

$$
C_{t}^{\prime}=A e^{-\frac{t}{b}}+B
$$

...where, $C_{t}^{\prime}$ represents the amounts of metal ions in the solution at $\mathrm{t}(\mathrm{min})(\mathrm{mg} / \mathrm{L}), \mathrm{A}, \mathrm{b}$ and $\mathrm{B}$ are constants.

\section{Results and Discussion}

\section{SEM (Scanning Electron Microscope) Analysis}

The surface morphology of $\mathrm{Cr}$ (III) biosorption was shown in Fig. 1. Before adsorption, the shapes of biosorbents in terms of cell structures were apparently different. The oval cell structure of TP huddled together, whereas XB and MY cells showed spherical and agglomerate structure. In addition, mycelial structure was observed in TQ cells with maintained original analogous shape. After the adsorption of $\mathrm{Cr}(\mathrm{III})$, the surface of biosorbents became smooth showing markedly lamellar cell structure, while gaps were partially filled. This is possibly because the functional groups on the cell surface bound with $\mathrm{Cr}$ (III) and the interspace among biosorbents was filled by $\mathrm{Cr}(\mathrm{III})$ precipitate.

\section{FTIR (Fourier Transform Infrared Spectroscopy) Analysis}

The FTIR spectroscopy method was employed to reveal the nature of possible interactions between the functional groups of four biosorbents and $\mathrm{Cr}$ (III). The FTIR spectra of unloaded and Cr-loaded biosorbents were presented in Fig. 2.

After sorption of $\mathrm{Cr}$ (III) on TP, the peak observed at $3364 \mathrm{~cm}^{-1}$ was shifted to $3382 \mathrm{~cm}^{-1}$. This might be 


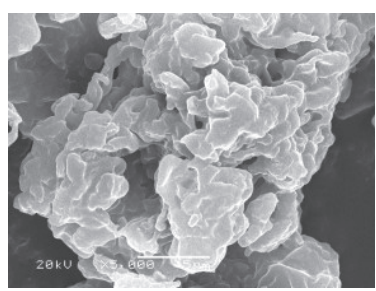

$\mathrm{TP}-\mathrm{i}$

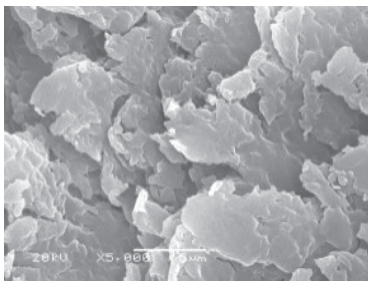

TP-ii

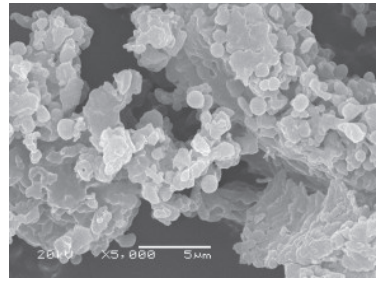

$\mathrm{XB}-\mathrm{i}$

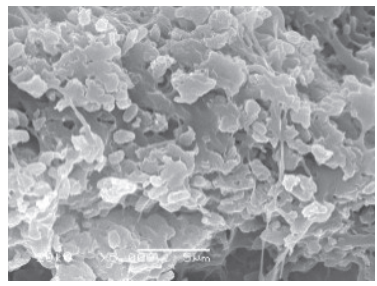

XB-ii

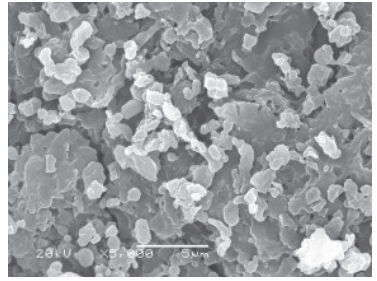

MY-i

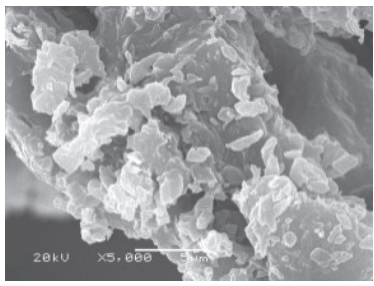

MY-ii

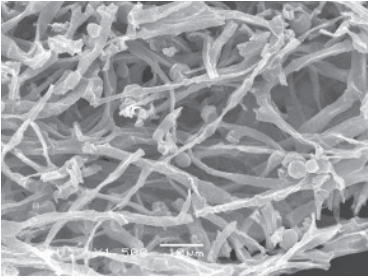

TQ-i

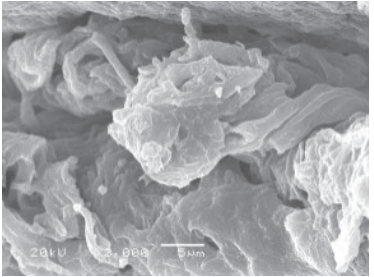

TQ-ii

Fig. 1. SEM pictures of 4 microbial biosorbents before (i ) and after (ii) uptaking $\mathrm{Cr}(\mathrm{III})(\times 5000)$.

caused by the overlapping of amino and hydroxy stretching vibration, indicating chemical binding of $\mathrm{Cr}$ with protein and carbohydrate substances on the cell surface. The peak of alcoholic and phenolic hydroxyl at $1404 \mathrm{~cm}^{-1}$ was shifted to $1381 \mathrm{~cm}^{-1}$, whereas a new peak appeared at $1544 \mathrm{~cm}^{-1}$. Further, the bond of carbonyl at $2854 \mathrm{~cm}^{-1}$ vanished only with peak at $613 \mathrm{~cm}^{-1}$ left. This demonstrated that the functional groups including $\mathrm{CH}_{2},-\mathrm{C}(=\mathrm{O}) \mathrm{O}-, \mathrm{N}-\mathrm{H}$ of amide, as well as phosphorusand sulfur-containing groups were involved in biosorption [21, 22].

When $\mathrm{Cr}$ (III) was adsorbed by XB, the peak at $3288 \mathrm{~cm}^{-1}$ was raised to 3382 and the disappeared peaks at $1403,896,825$ and $700 \mathrm{~cm}^{-1}$ indicated that $-\mathrm{OH}$, - $\mathrm{CH}$ and amide $\mathrm{V}$ bonds changed with banding $\mathrm{Cr}$ (III). Moreover, new band at $1554 \mathrm{~cm}^{-1}$ and weak peaks at 1292 and $621 \mathrm{~cm}^{-1}$ showed that carboxyl groups, phosphorus and sulfur-containing functional groups and amide $\mathrm{V}$ also adsorbed $\mathrm{Cr}$ (III) ions [23].

When MY was exposed to $\mathrm{Cr}(\mathrm{III})$ solution, peaks at 699 and $896 \mathrm{~cm}^{-1}$ disappeared, while new peak was found at $1101 \mathrm{~cm}^{-1}$. Besides, bands at 3291 and $1647 \mathrm{~cm}^{-1}$ were shifted up to 3367 and $1657 \mathrm{~cm}^{-1}$, respectively. It was reported that the $\mathrm{Cr}$ (III) biosorption of MY was connected with $\mathrm{C}-\mathrm{H}$ of $\mathrm{CH}_{3}$ and $\mathrm{CH}_{2}$ and $\mathrm{O}-\mathrm{H}$ bonds [24]. However, the adsorption capacity of MY was below other biosorbents which may be resulted from less adsorption functional groups.

After TQ contacted with $\mathrm{Cr}$ (III), peak at $3349 \mathrm{~cm}^{-1}$ was shifted to $3391 \mathrm{~cm}^{-1}$, and peaks at 1744, 1378, 1251, 1139 and $1039 \mathrm{~cm}^{-1}$ disappeared. In addition, new peaks appeared at 2853 and $1413 \mathrm{~cm}^{-1}$. The results showed that $-\mathrm{OH}$, amino and aliphatic carbon $\mathrm{CH}_{2}$ bonds of biosorbents could combine with $\mathrm{Cr}$ ions directly and the configuration of carboxyl, hydroxyl and polysaccharide groups changed after adsorption. In addition, the amide III bond was observed with the change of other adsorption groups [25].

Above on, the $\mathrm{Cr}(\mathrm{III})$-loaded band of biosorbent was essentially the same with unloaded. However, we observed that the $\mathrm{C}-\mathrm{N}$ and $\mathrm{N}-\mathrm{H}$ bonds of amido groups, the $\mathrm{O}-\mathrm{H}$ bond of hydroxyl groups, carboxyl, hydrocarbyl and phosphorus and sulfur-containing functional groups were effective in the $\mathrm{Cr}$ (III) biosorption.

\section{Effect of Contact Time}

Contact time of biosorbent was one of the key parameters for rapid adsorption and practical application. Fig. 3 showed the result of contact time (12 h) on the biosorption of $\mathrm{Cr}(\mathrm{III})$. The adsorption curves of four biosorbents were almost smooth and continuous, implying the $\mathrm{Cr}$ (III) ions were monolayer adsorption at the surface of biomass [26]. The adsorption process as a function of time can be divided into two phrases: the rapid adsorption phrase during which the initial adsorption rate was fast, and the slow adsorption phase during which the adsorption capacity slightly changed after $120 \mathrm{~min}$. This was mainly because biomass had more active sites at the initial adsorption process to bind with $\mathrm{Cr}$ (III) ions, then high $\mathrm{Cr}$ (III) ion concentration gradient in the aqueous solution provided greater driving force to support ions against the resistance of solid-liquid interface. As the adsorption proceeded further, the rate of biosorption was slowly decreased because of the occupation of $\mathrm{Cr}$ (III) on adsorption sites. After $120 \mathrm{~min}$, the q of TP, XB, MY and TQ was 6.92, 10.35, 9.20 and $8.72 \mathrm{mg} / \mathrm{g}$ respectively, and remained stable. Therefore, the optimum rapid contact time for adsorption was defined as $120 \mathrm{~min}$. 

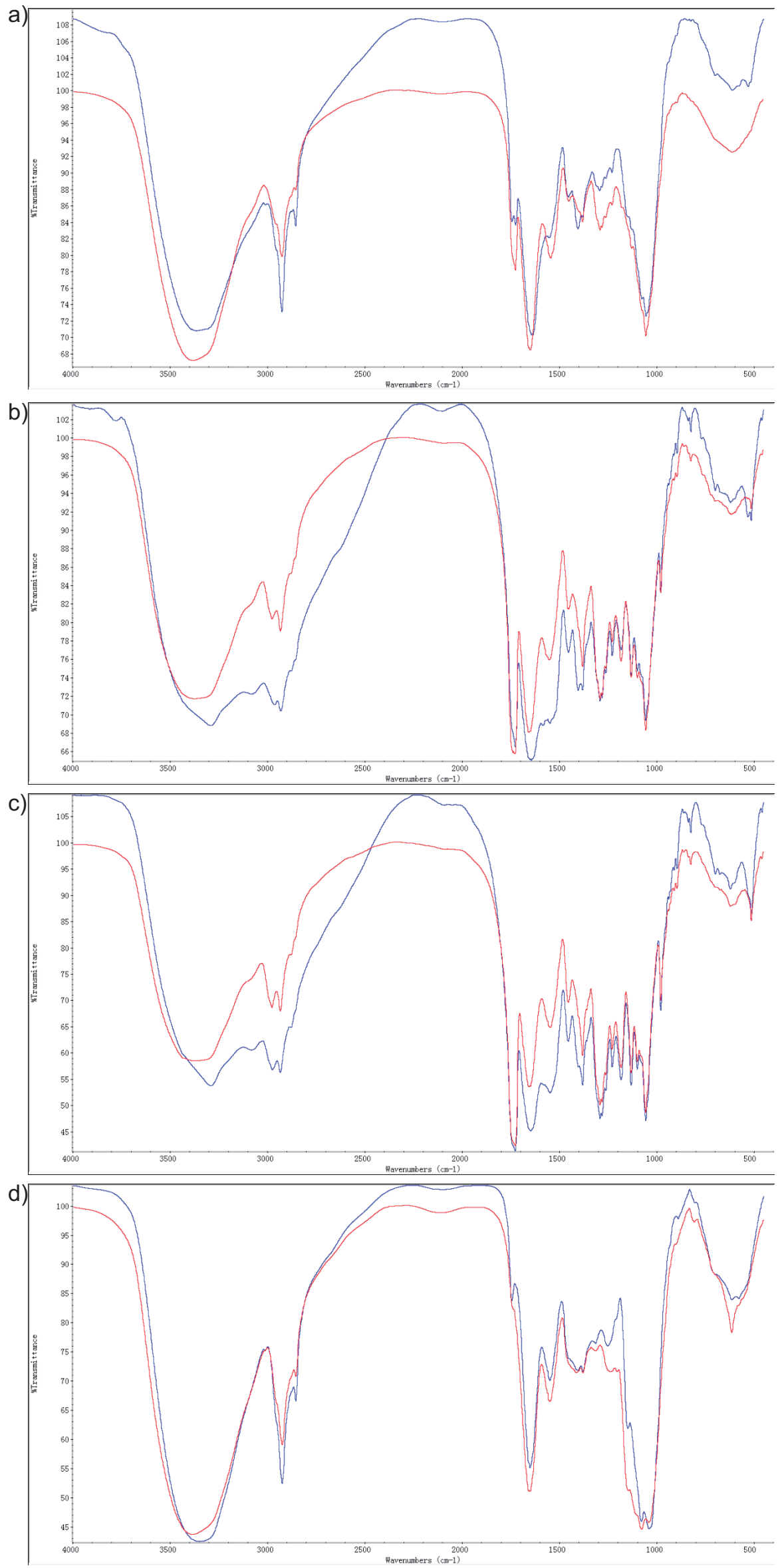

Fig. 2. FTIR of biosorbent before and after biosorption of $\mathrm{Cr}$ (III)

(The a, b, c, d were TP, XB, MY and TQ; The blue line was the Control sample, and the red line wasd Cr-load). 


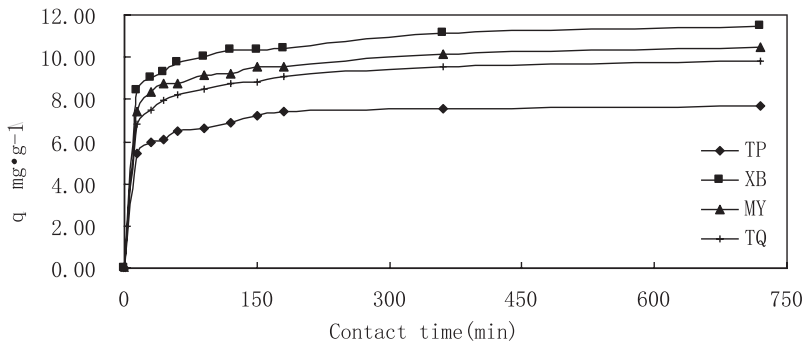

Fig. 3. Effect of contact time on the biosorption of $\mathrm{Cr}(\mathrm{III})$ (Metal concentration: $5.0 \mathrm{mg} / \mathrm{L}$; dosage: $0.5 \mathrm{~g} / \mathrm{L}$; temperature: $30^{\circ} \mathrm{C}$; contact time: $\left.12 \mathrm{~h} ; \mathrm{pH}: 4\right)$.

\section{Biosorption Isotherm Models}

\section{Langmuir Isotherm Model}

The Langmuir isotherm model is based on gassolid adsorption theory. It is also used in liquid-solid adsorption because of the applicability of invovled parameters in the equation. It assumes that monolayer adsorption occurs on a homogeneous surface and the adsorption heat does not change with the coverage rate. There is no interaction between adsorption molecules. The constant values obtained for the linearized Langmuir isotherm were presented in Table 1, whereas the linear relationship was showed in Fig 4. The coefficient of determination $\left(\mathrm{R}^{2}\right)$ of four biosorbents were $0.9743,0.8949,0.9479$ and 0.9819 , respectively. This indicated that except XB, the biosorption of $\mathrm{Cr}$ (III) fitted well with the Langmuir isotherm model. In other words, the adsorption of $\mathrm{Cr}$ (III) ions binding by the functional groups or active sites on the surface of TP, MY and TQ was monolayer adsorption [27].

\section{Freundlich Isotherm Model}

When the adsorption heat changes with the coverage rate, introduction of Freundlich and Temkin isotherm models is needed to describe the adsorption. The Freundlich isotherm model assumed a monolayer adsorption with a heterogeneous energetic distribution of active sites and biosorbent molecules interact with each other.

Fig. 5 indicated the linear relationship of Freundlich isotherm model for the biosorption of $\mathrm{Cr}(\mathrm{III})$ ions, and Table 2 shows the related coefficients obtained from the fitted equation. Compared with Langmuir isotherm

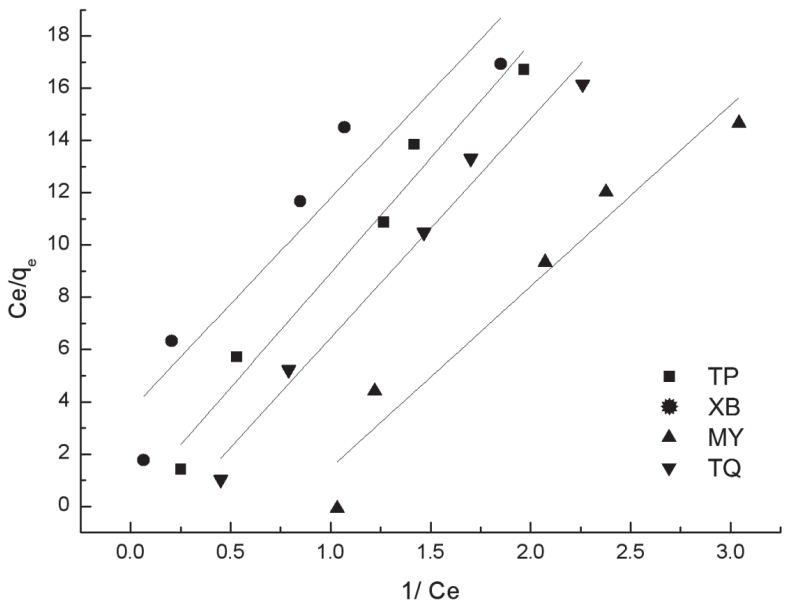

Fig. 4. Langmuir isotherm plots for biosorption of $\mathrm{Cr}(\mathrm{III})$.

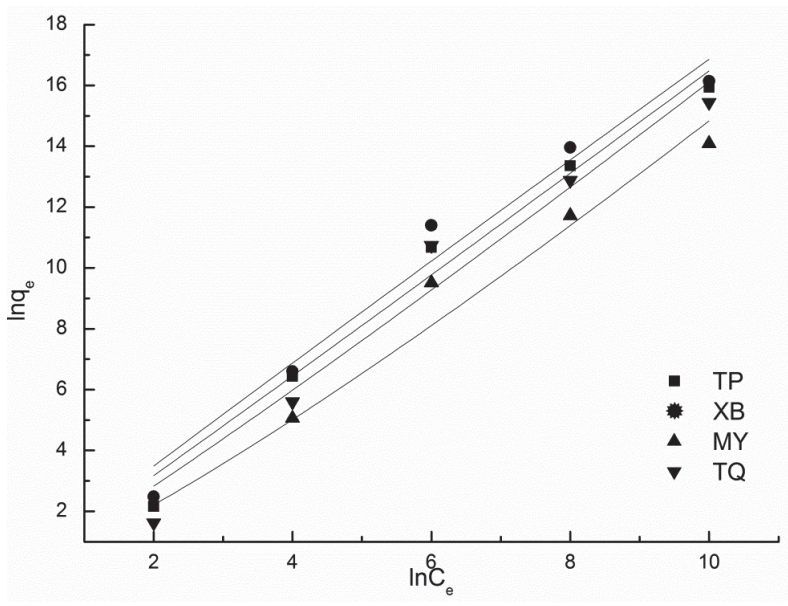

Fig. 5. Freundlich isotherm plots for biosorption of $\mathrm{Cr}(\mathrm{III})$.

model, Freundlich isotherm model is more suitable for the biosorption of $\mathrm{XB}$ and the $\mathrm{R}^{2}$ is 0.9322 . According to $\mathrm{R}^{2}$ values, TP had a small change, while MY and TQ decreased from 0.9479 and 0.9819 to 0.9146 and 0.9677 respectively. All of $1 / \mathrm{n}$ values were between 0 and 2 indicating that the biosorption of $\mathrm{Cr}$ (III) was favorable $[28,29]$.

\section{Temkin Isotherm Model}

The derivation of the Temkin isotherm model assumes that the decline in the heat of sorption is

Table 1. Langmuir isothermal equation of biosorption and correlative constants

\begin{tabular}{|c|c|c|c|c|}
\hline Biosorbents & Langmuir isotherm model & $q_{\mathrm{m}}\left(\mathrm{mg} \cdot \mathrm{g}^{-1}\right)$ & $b$ & $R^{2}$ \\
\hline TP & $1 / q=0.075 / c_{e}+0.043$ & 26.816 & 0.497 & 0.9743 \\
\hline XB & $1 / \mathrm{q}=0.027 / \mathrm{ce}+0.046$ & 19.272 & 1.946 & 0.8949 \\
\hline MY & $1 / \mathrm{q}=0.527 / \mathrm{ce}+0.064$ & 16.860 & 0.113 & 0.9479 \\
\hline TQ & $1 / \mathrm{q}=0.111 / \mathrm{ce}+0.052$ & 21.353 & 0.421 & 0.9819 \\
\hline
\end{tabular}


Table 2. Freundlich isothermal equation of biosorption and correlative constants.

\begin{tabular}{|c|c|c|c|c|}
\hline Biosorbents & Freundlich isotherm model & $k$ & $1 / n$ & $R^{2}$ \\
\hline TP & $q_{e}=8.421 c_{e}^{0.912}$ & 8.421 & 0.912 & 0.9708 \\
\hline XB & $q_{e}=11.518 c_{e}^{0.689}$ & 11.518 & 0.689 & 0.9322 \\
\hline MY & $q_{e}=2.866 c e^{1.227}$ & 2.866 & 1.227 & 0.9146 \\
\hline TQ & $q_{e}=6.238 c_{e}^{1.076}$ & 6.238 & 1.076 & 0.9677 \\
\hline
\end{tabular}

linear rather than logarithmic with coverage due to adsorbent-adsorbate interactions. The adsorption is characterized by a uniform distribution of the binding energies [22].

The adsorption data was analyzed according to the linear form of the Temkin isotherm and the linear plots were showed in Fig. 6. The experimental data revealed that XB was fitted better compared to the Freundlich isotherm model and the $\mathrm{R}^{2}$ was 0.9427 which was higher than the $\mathrm{R}^{2}$ of Freundlich equation 0.9322 . The $\mathrm{R}^{2}$ values presented in Table 3 showed that the biosorption except MY fitted well with Temkin isotherm model. This indicated that interaction force occurred with absorbed solute when the adsorbing material adsorb solute affects isothermal adsorption behavior. In the adsorption process of $\mathrm{Cr}$ (III), the data indicated that according to the change of interaction force, the surface coverage of adsorbent increased while the adsorption heat decreased linearly.

\section{Dubimim-Radushkevich Isotherm Model}

The D-R isotherm model assumes that there is a surface area where the adsorption energy is homogeneous. Except MY, the results in Table 4. and Fig. 7. indicated that there was a relatively good correlation with D-R isotherm model, as well as the $\mathrm{R}^{2}$ value of TP, XB and TQ (0.9679, 0.9192 and 0.9682 respectively). By calculating the mean biosorption energy ( $\mathrm{E}$ value), the nature of biosorption can be determined [30, 31]. When $\mathrm{E}$ value is between 8 and $16 \mathrm{KJ} / \mathrm{mol}$, the biosorption process is of chemical ion-exchange, while if $\mathrm{E}<8 \mathrm{KJ} / \mathrm{mol}$, the adsorption process belongs to a physical nature $[32,33]$. The mean biosorption energy of TP, XB and TQ was 13.73, 13.22 and $11.84 \mathrm{KJ} / \mathrm{mol}$ by calculation. These values are all between 8 and $16 \mathrm{KJ} / \mathrm{mol}$, which suggests that the $\mathrm{Cr}$ (III) biosorption process of the three biosorbents was possibly inclined to be chemical ion-exchange .
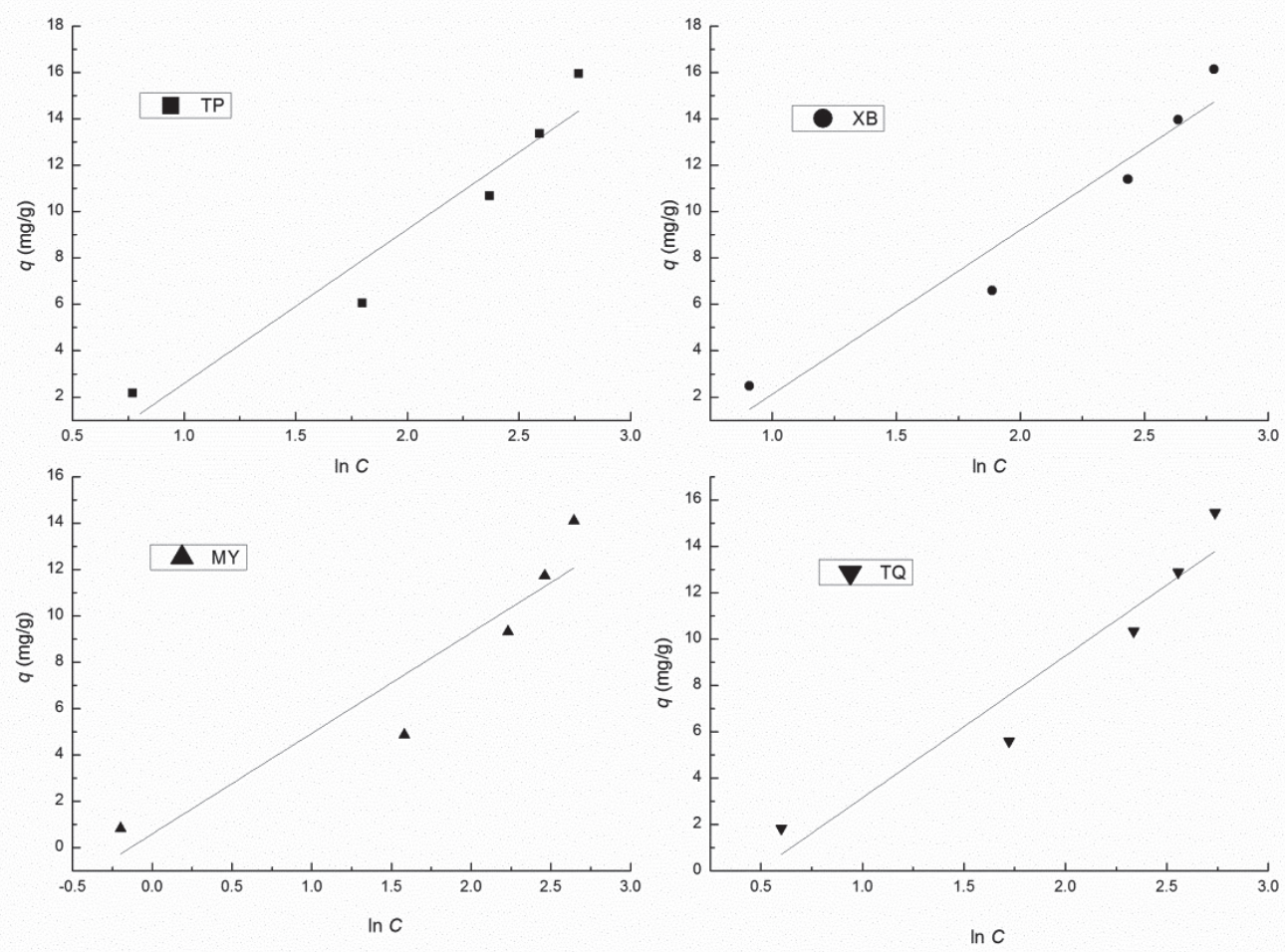

Fig. 6. Temkin isotherm plots for biosorption of $\mathrm{Cr}(\mathrm{III})$. 
Table 3. Temkin isothermal equation of biosorption and correlative constants.

\begin{tabular}{|c|c|c|c|c|}
\hline Biosorbents & Temkin isotherm model & $k_{1}$ & $\ln k_{2}$ & $R^{2}$ \\
\hline TP & $q=6.64 \ln (0.54 \mathrm{c})$ & 6.64 & -0.61 & 0.9333 \\
\hline XB & $q=7.07 \ln (0.50 \mathrm{c})$ & 7.07 & -0.70 & 0.9427 \\
\hline MY & $q=4.34 \ln (1.15 \mathrm{c})$ & 4.34 & 0.14 & 0.8850 \\
\hline TQ & $q=6.12 \ln (0.61 \mathrm{c})$ & 6.12 & -0.48 & 0.9265 \\
\hline
\end{tabular}
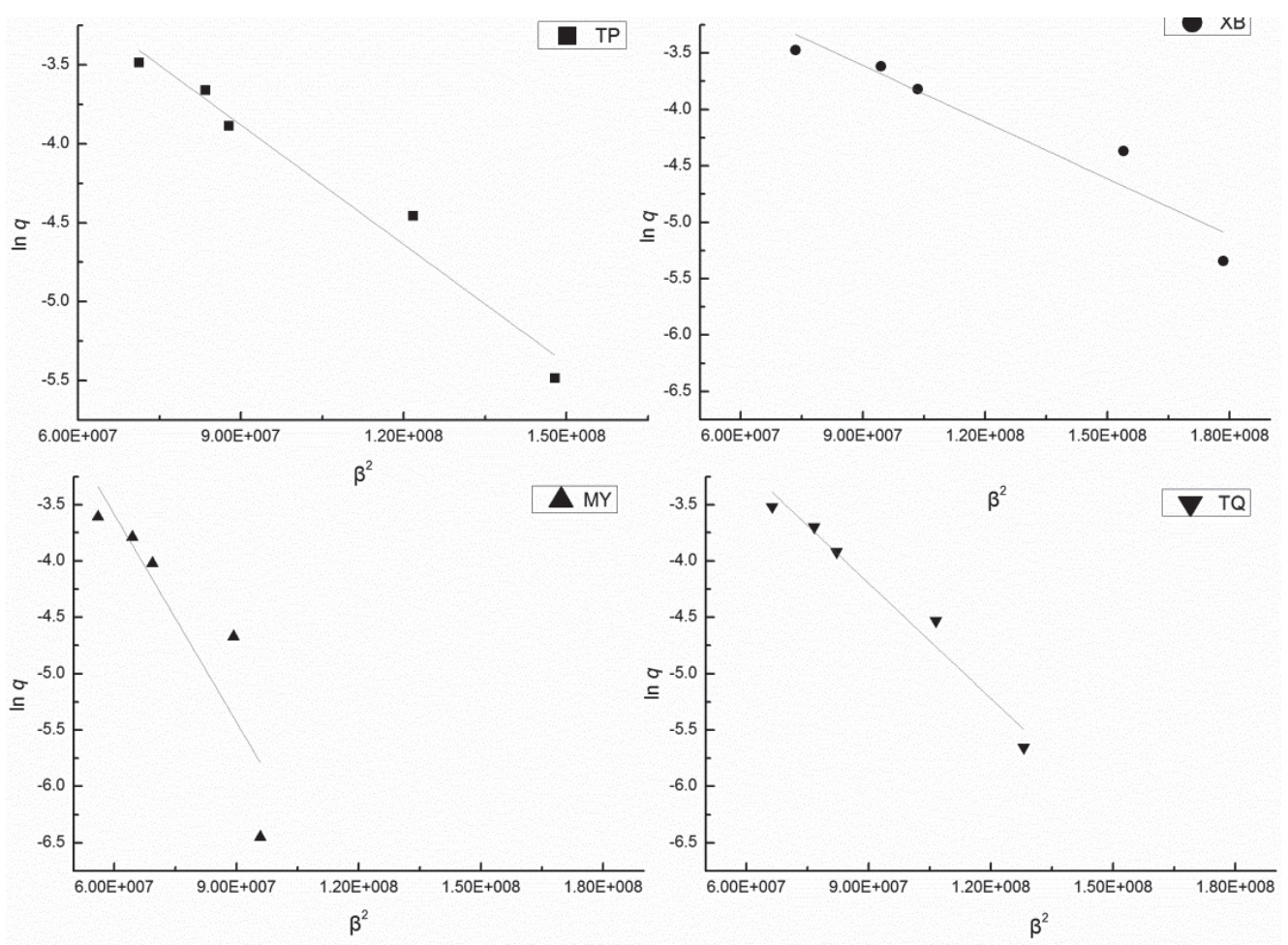

Fig. 7. Dubimim-Radushkevich (D-R) isotherm plots for biosorption of $\mathrm{Cr}(\mathrm{III})$.

\section{Biosorption Kinetics}

\section{Lagergren Model}

The plots of $\ln (q \mathrm{e}-\mathrm{qt})$ vs $t$ for the pseudo-firstorder model and the linear plots of t/qt vs $t$ for the pseudo-second-order model were showed in Fig. 8. and correlation parameters were given in Table 5. Because of the low $\mathrm{R}^{2}$ and significant difference between the theoretical values (q1) and the measured values (qe) showed in Table 5, the biosorption mechanism of $\mathrm{Cr}$ (III) onto four biosorbents did not follow the pseudo-firstorder kinetic model meaning the adsorption rate was not determined by the amount of free active sites on the surface of biosorbents.

Experimental data was also tested by the pseudosecond-order kinetic model. It was clear that the $\mathrm{R}^{2}$ values were high (in range of 0.9997-0.9999) and the theoretical result $\left(\mathrm{q}_{1}\right)$ coincided with the measured value $\left(\mathrm{q}_{\mathrm{e}}\right)$. It is evident that Lagergren pseudo-second-

Table 4. Dubimim-Radushkevich isothermal equation of biosorption and correlative constants.

\begin{tabular}{|c|c|c|c|c|c|}
\hline Biosorbents & D-R isotherm model & $\begin{array}{c}q_{\mathrm{m}} \\
\left(\mathrm{mol} \cdot \mathrm{g}^{-1}\right)\end{array}$ & $\begin{array}{c}\beta \\
\left(\mathrm{mol}^{2} \cdot \mathrm{J}^{-2}\right)\end{array}$ & $\begin{array}{c}\mathrm{E} \\
\left(\mathrm{KJ} \cdot \mathrm{mol}^{-1}\right)\end{array}$ & $R^{2}$ \\
\hline TP & Ln $q=-1.61-2.52 \times 10^{-8} \varepsilon$ & 0.1996 & 0.497 & 13.73 & 0.9679 \\
\hline XB & Ln $q=-2.11-1.67 \times 10^{-8} \varepsilon$ & 0.1216 & 1.946 & 13.22 & 0.9192 \\
\hline MY & $\operatorname{Ln} q=0.09-6.14 \times 10^{-8} \varepsilon$ & 1.0971 & 0.113 & 53.47 & 0.8041 \\
\hline TQ & Ln $q=-1.13-3.41 \times 10^{-8} \varepsilon$ & 0.3217 & 0.421 & 11.84 & 0.9682 \\
\hline
\end{tabular}


Table 5. Kinetic parameters obtained from pseudo-first-order and second-first-order on the biosorption of $\mathrm{Cr}(\mathrm{III})$.

\begin{tabular}{|c|c|c|c|c|c|c|c|c|}
\hline \multirow{2}{*}{ Biosorbents } & \multirow{2}{*}{$q_{e}\left(\mathrm{mg} \cdot \mathrm{g}^{-1}\right)$} & \multicolumn{3}{|c|}{ Pseudo-first-order } & \multicolumn{4}{c|}{ Pseudo-second-order } \\
\cline { 3 - 10 } & & $K_{l}\left(\mathrm{~min}^{-1}\right)$ & $q_{l}(\mathrm{mg} / \mathrm{g})$ & $R^{2}$ & $K_{2}\left(\mathrm{~min}^{-1}\right)$ & $q_{2}(\mathrm{mg} / \mathrm{g})$ & $h_{o}\left(\mathrm{mg} / \mathrm{g} \cdot \mathrm{min}^{-1 / 2}\right)$ & $R^{2}$ \\
\hline TP & 8.66 & $7.13 \times 10^{-2}$ & 2.32 & 0.6859 & $7.13 \times 10^{-2}$ & 7.75 & 0.70 & 0.9999 \\
\hline XB & 11.65 & $2.17 \times 10^{-1}$ & 2.55 & 0.9624 & $2.17 \times 10^{-1}$ & 11.51 & 0.89 & 0.9998 \\
\hline MY & 11.05 & $1.20 \times 10^{-1}$ & 2.59 & 0.8869 & $1.20 \times 10^{-1}$ & 10.5 & 0.80 & 0.9997 \\
\hline TQ & 10.22 & $1.44 \times 10^{-1}$ & 2.41 & 0.8804 & $1.44 \times 10^{-1}$ & 9.85 & 0.74 & 0.9998 \\
\hline
\end{tabular}
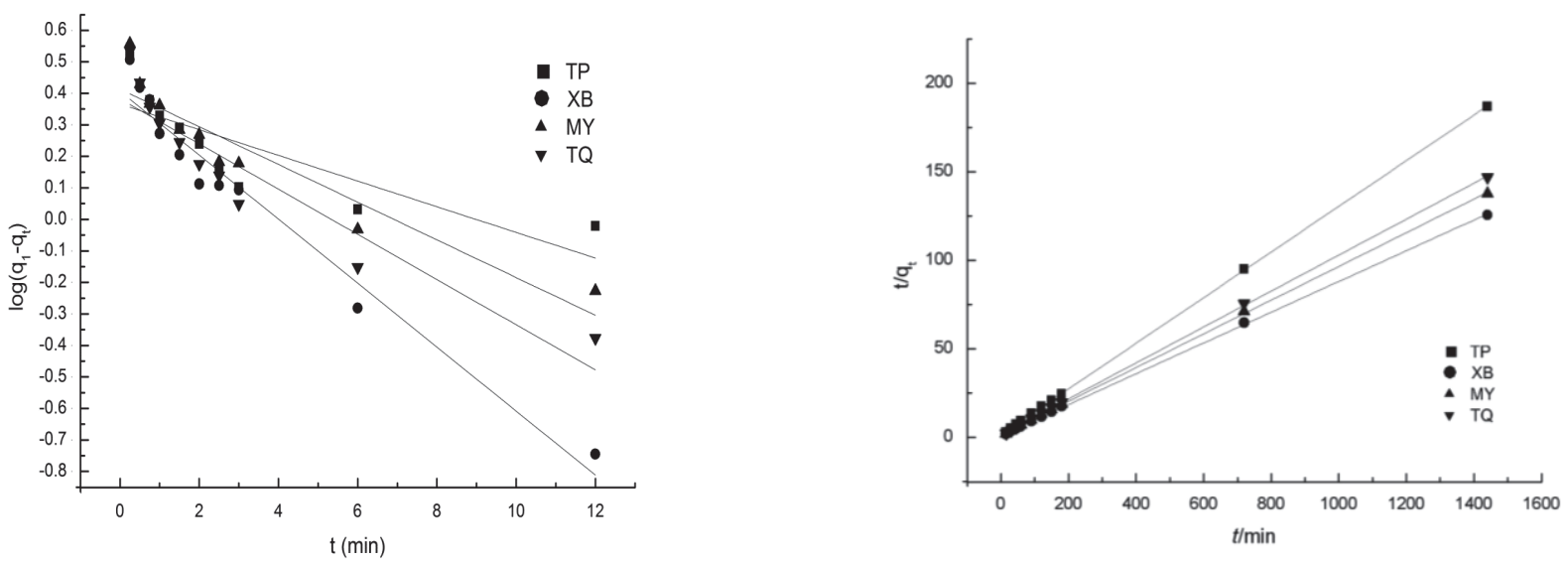

Fig. 8. Kinetic obtained from pseudo-first-order (up) and pseudo-second-order (down) on the biosorption of Cr(III).

order adsorption models are suitable to describe the adsorption kinetics of $\mathrm{Cr}$ (III) by four biomasses. These results conforms conclusion form previous reports, that is, the adsorption rate was determined by the squared value of free active sites $[22,34]$. Besides, the $\mathrm{Cr}(\mathrm{III})$ adsorption capacity of four biosorbents was in the sequence of $\mathrm{XB}>\mathrm{MY}>\mathrm{TP}>\mathrm{TQ}$ by the comparison of equilibrium adsorption.

\section{Intraparticle Diffusion Model}

In the adsorption process, boundary layer resistance or film diffusion were not major rate-limiting factors. On the other hand, the intraparticle diffusion showed considerable rate-limiting effect and the uptake of the adsorbate varies with the square root of time [35]. Table 6 showed that plotting the biosorption capacity against square root of time generates good linear for the $12 \mathrm{~h}$ of adsorption. The fitting of intraparticle diffusion model in Fig. 9 indicated that adsorption process was complex and involves several mechanisms. The first stage was the external surface adsorption, and the second was the gradual adsorption, which the intraparticle diffusion was rate-limiting factor. The third stage was the final equilibrium adsorption. When the biosorbent exterior surface reached saturation, the metal ions entered the pore within the biomass particle and were adsorbed by the interior surface of the particle [36]. Comparing the intraparticle diffusion rate constants, it was obvious that $\mathrm{kp} 1$ (first stage) $>\mathrm{kp} 2$ (second stage) $>\mathrm{kp} 3$ (third stage).

\section{Desorption and Regeneration Analysis}

As is shown in Fig. 10, it could be seen that $0.5 \mathrm{ml} / \mathrm{L}$ $\mathrm{HCl}$ solution has good effect as desorbent, and the four biosorbents fit well with the exponential decay model, and the exponential decay model could describe the

Table 6 .Kinetic parameters obtained from intraparticle diffusion model on the biosorption of $\mathrm{Cr}(\mathrm{III})$.

\begin{tabular}{|c|c|c|c|c|c|c|}
\hline Biosorbents & $\begin{array}{c}k_{\mathrm{p} 1} \\
\left(\mathrm{mg} \cdot \mathrm{g}^{-1} \cdot \mathrm{min}^{-1 / 2}\right)\end{array}$ & $R_{\mathrm{p} 1}{ }^{2}$ & $\begin{array}{c}k_{\mathrm{p} 2} \\
\left(\mathrm{mg} \cdot \mathrm{g}^{-1} \cdot \mathrm{min}^{-1 / 2}\right)\end{array}$ & $R_{\mathrm{p} 2}{ }^{2}$ & $\begin{array}{c}k_{\mathrm{p} 3} \\
\left(\mathrm{mg} \cdot \mathrm{g}^{-1} \cdot \mathrm{min}^{-1 / 2}\right)\end{array}$ & $R_{\mathrm{p} 3}{ }^{2}$ \\
\hline TP & 0.3027 & 0.9826 & 0.1787 & 0.9904 & 0.0234 & 0.9579 \\
\hline XB & 0.3294 & 0.9775 & 0.1149 & 0.8883 & 0.0774 & 0.9150 \\
\hline MY & 0.3469 & 0.8885 & 0.1418 & 0.9417 & 0.0669 & 0.9396 \\
\hline TQ & 0.3651 & 0.9878 & 0.1544 & 0.9911 & 0.0511 & 0.9550 \\
\hline
\end{tabular}




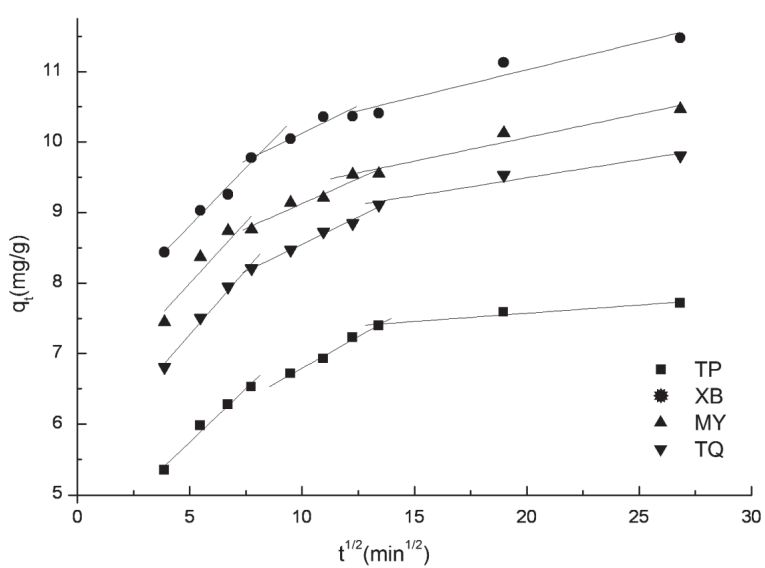

Fig. 9. Intraparticle diffusion kinetics on the biosorption of Cr(III).

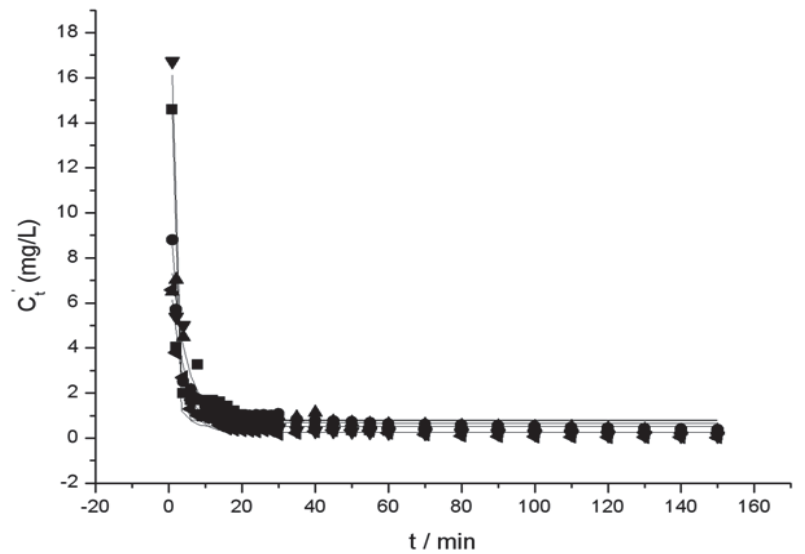

Fig. 10. Desorption kinetic curve for $\mathrm{Cr}(\mathrm{III})$ of four biodsorbent.

Table 7. Kinetic parameters obtained from Exponential decay kinetic model on the biosorption of Cr(III) by four biosorbents.

\begin{tabular}{|c|c|c|c|c|c|}
\hline Biosorbents & $\mathrm{A}$ & $\mathrm{B}$ & $-1 / \mathrm{b}$ & Kinetic model & $R^{2}$ \\
\hline $\mathrm{TP}$ & 54.834 & 0.778 & -1.382 & $C_{t}^{\prime}=54.834 * e^{-1.382 t}+0.778$ & 0.9271 \\
\hline $\mathrm{XB}$ & 11.790 & 0.793 & -0.415 & $C_{t}^{\prime}=11.790 * e^{-0.415 t}+0.793$ & 0.9707 \\
\hline $\mathrm{MY}$ & 8.344 & 0.668 & -0.228 & $C_{t}^{\prime}=8.344 * e^{-0.228 t}+0.668$ & 0.9527 \\
\hline $\mathrm{TQ}$ & 35.337 & 0.522 & -0.818 & $C_{t}^{\prime}=35.337 * e^{-0.522 t}+0.522$ & 0.9401 \\
\hline
\end{tabular}

Table 8. Effect of regeneration on sorption for Cr(III) of immobilized microbial adsorbents.

\begin{tabular}{|c|c|c|c|c|c|}
\hline Biosorbents & Cycles & Post-adsorption (mg/L) & $\mathrm{Q}(\%)$ & Post-desorptio (mg/L) & DQ (\%) \\
\hline \multirow{4}{*}{$\mathrm{TP}$} & 1 & 0.52 & 89.32 & 4.42 & 90.76 \\
\hline & 2 & 0.77 & 84.19 & 4.37 & 89.73 \\
\hline & 3 & 0.96 & 80.29 & 3.94 & 80.90 \\
\hline & 4 & 1.14 & 76.59 & 3.85 & 79.06 \\
\hline \multirow{4}{*}{$\mathrm{XB}$} & 1 & 1.13 & 76.80 & 4.36 & 89.53 \\
\hline & 2 & 1.28 & 73.72 & 4.21 & 86.45 \\
\hline & 3 & 1.31 & 73.10 & 4.06 & 83.37 \\
\hline & 4 & 1.45 & 70.23 & 3.82 & 78.44 \\
\hline \multirow{4}{*}{ MY } & 1 & 1.26 & 74.13 & 4.33 & 88.91 \\
\hline & 2 & 1.42 & 70.84 & 4.02 & 82.55 \\
\hline & 3 & 1.55 & 68.17 & 3.79 & 77.82 \\
\hline & 4 & 1.67 & 65.71 & 3.55 & 72.90 \\
\hline \multirow{4}{*}{ TQ } & 1 & 0.32 & 93.43 & 4.59 & 94.25 \\
\hline & 2 & 0.48 & 90.14 & 4.44 & 91.17 \\
\hline & 3 & 0.66 & 86.45 & 4.18 & 85.83 \\
\hline & 4 & 0.89 & 81.72 & 4.03 & 82.75 \\
\hline
\end{tabular}


desorption of heavy metal concentration in the system. It revealed that the order of $\mathrm{R}^{2}$ was $\mathrm{XB}>\mathrm{MY}>\mathrm{TQ}>\mathrm{TP}$. And it could be observed in Fig. 10, the desorption kinetic process of the adsorbent can be divided into 2 stages: fast reaction and slow reaction. According to the previous study on the adsorption kinetics, desorption as the inverse process of adsorption, the Cr(III) adsorbed inside the particles of biosorbent needed the diffusion process to move out of the particles into the solution. Therefore, a large number of $\mathrm{H}^{+}$had to continuously enter and bind to the adsorbent sites in order to desorb $\mathrm{Cr}$ (III), and with the large amount of $\mathrm{Cr}$ (III) released from the surface layer, it takes longer to desorb $\mathrm{Cr}$ (III) from the deep sites, resulting in a slowdown of the desorption rate $[37,38]$.

In Table 8, it showed that the adsorption and desorption rates of the four biosorbents decreased gradually with the increase of the number of repeated use. Due to the incomplete desorption of $\mathrm{Cr}$ (III) from the biosorbents, a small amount of heavy metal ions remained in adsorption sites, which occupied the binding groups on the surface of the adsorbent, so that the adsorption effect was affected when it was used repeatedly. And because of the deformation of the adsorption sites and the change of the surface groups of the biosorbents after repeated acidic and neutral treatments, the adsorption capacity of $\mathrm{Cr}$ (III) also decreased. Moreover, the adsorption effect was affected by repeated acidic and neutral conditions, which affected the surface binding groups of the microbial adsorbent and thus the adsorption results. The results showed that the desorption rate of TQ could be maintained above $80 \%$ after four times of repeated use, showing good stability and reproducibility. The results also showed that the desorption rate of TQ could be maintained above $80 \%$ after 4 times of reuse, showing good stability and reproducibility.

\section{Conclusions}

The four dried biosorbents (TP, XB, MY and TQ) can successfully remove $\mathrm{Cr}$ (III) ions from the low concentration aqueous solution. Investigating the apparent structure of microbial adsorbent will be helpful in understanding the mechanism adopted by different microbes and results as follows.

After the adsorption of $\mathrm{Cr}(\mathrm{III})$, the surface of microbial adsorbents become smooth and parts of gap were filled. And functional groups on the surface of bacterial adsorbents including $\mathrm{CH}$ groups, carboxyl, polyglucose, amine, phosphoric acid and sulfur functional groups were useful.

The biosorption of TP, MY and TQ were fitted well with Langmuir isotherm model and their functional groups or activity sites on the surface was monolayer adsorption. XB was fitted well with Temkin model and the surface coverage of it increased while the adsorption heat decreased linearly. The result of fitting
$\mathrm{D}-\mathrm{R}$ isotherm model revealed that biosorption of $\mathrm{TP}$, $\mathrm{XB}$ and TQ was ion-exchange adsorption.

The kinetics of adsorption followed the pseudosecond-order kinetic model suggesting the adsorption rate was determined by the squared value of free active sites. The intraparticle diffusion model suggested that four biosorption present three steps and the first section was the rate-controlling one. Moreover, the maximal adsorption capacities arranged in the following order: $\mathrm{XB}>\mathrm{MY}>\mathrm{TP}>\mathrm{TQ}$ (According the adsorption equilibrium data $11.51,10.5,7.75$ and $9.85 \mathrm{mg} / \mathrm{g}$ ).

The desorption of the biosorbents conformed to the exponential decay equation, and the order of fit was $\mathrm{XB}>\mathrm{MY}>\mathrm{TQ}>\mathrm{TP}$. After four times of reuse, all four biosorbents still had the adsorption effect, and TQ was the most effective, which the desorption rate could be maintained at more than $80 \%$.

\section{Acknowledgments}

The authors would like to acknowledge the financial support from the Science and technology innovation project of the functional development of instrument and equipment of the Chinese Academy of Sciences (Y6R4200200).

\section{Conflict of Interest}

The authors declare no conflict of interest.

\section{References}

1. WEI W., LI A., MA F., PI S., YANG J., WANG Q., NI B. Simultaneous sorption and reduction of $\mathrm{Cr}(\mathrm{VI})$ in aquatic system by microbial extracellular polymeric substances from Klebsiella sp. J1. Journal of Chemical Technology and Biotechnology, 93, 3152, 2018.

2. NABA K. M., ANGELA S., SUKALYAN C., WASIM A.S. Enhanced chromium(VI) removal using banana peel dust: isotherms, kinetics and thermodynamics study. Sustainable Water Resources Management, 4, 489, 2018.

3. SANDHYA M., RAM N.B. Toxic and genotoxic effects of hexavalent chromium in environment and its bioremediation strategies. Journal of Environmental Science and Health, Part C, Environ Carcinog Ecotoxicol Rev, 34, 1, 2016.

4. SAMARAWEERA A.P.G.M.V., PRIYANTHA N., GUNATHILAKE W.S.S., KOTABEWATTA P.A., KULASOORIYA T.P.K. Biosorption of Cr(III) and $\mathrm{Cr}$ (VI) species on $\mathrm{NaOH}$-modified peel of Artocarpus nobilis fruit. 1. Investigation of kinetics, Applied Water Science, 10, 115, 2020.

5. OJIAGU K.D., ODIBO F.J.C., OJIAGU N.C., AGU K.C., OKAFOR A.C. Biosorption of hexavalent chromium by Pseudomonas aeruginosa strain ANSC: Equilibria isothermic, kinetic and thermodynamic studies. Bioengineering and Bioscience, 6, 1, 2018.

6. RAI M.K., GIRI B.S., NATH Y., BAJAJ H., SONI S., SINGH R.P., SINGH R.S., RAI B.N. Adsorption of 
hexavalent chromium from aqueous solution by activated carbon prepared from almond shell: kinetics, equilibrium and thermodynamics study. Journal of Water Supply: Research and Technology-Aqua, 67, 724, 2018.

7. LIU C., DING Y., WU W., TENG Y. A simple and effective strategy to fast remove chromium (VI) and organic pollutant in photoelectrocatalytic process at low voltage. Chemical Engineering Journal, 306, 22, 2016.

8. QIN N., ZHANG Y., ZHOU H., GENG Z., LIU G., ZHANG Y., ZHAO H., WANG G. Enhanced removal of trace $\mathrm{Cr}(\mathrm{VI})$ from neutral and alkaline aqueous solution by FeCo bimetallic nanoparticles. J. Colloid. Interf. Sci. 472, 8, 2016.

9. FEKADU M., GIJS D. L., ARGAW A., ESAYAS A. Application of freeze desalination for chromium(VI) removal from water. Desalination. 377, 23, 2016.

10. JYOTHI M.S., NAYAK V., PADAKI M., BALAKRISHNA R.G., SOONTARAPA K. Aminated polysulfone/ $\mathrm{TiO}_{2}$ composite membranes for an effective removal of $\mathrm{Cr}(\mathrm{VI})$. Chem. Eng. J. 283, 1494, 2016.

11. QIU W.M., YANG D., XU J.C., HONG B., JIN H.X., JIN D.F., PENG X.L., J. LI, H.L. GE, X.Q. Wang, Efficient removal of $\mathrm{Cr}(\mathrm{VI})$ by magnetically separable $\mathrm{CoFe}_{2} \mathrm{O}_{4} /$ activated carbon composite. J. Alloys Compd. 678, 179, 2016.

12. HIRA S., UZAIRA R., ROBERT P.D. Investigations on post-synthetically modified UiO-66-NH2 for the adsorptive removal of heavy metal ions from aqueous solution. Microporous Mesoporoius Mater. 221, 238, 2016.

13. COCHRANE EL., LU S., GIBB S.W., VILLAESCUSA I. A comparison of low-cost biosorbents and commercial sorbents for the removal of copper from aqueous media, Journal of Hazardous Materials, 137, 198, 2006.

14. CAMILA S.D.C., BRUNO G.M.Q., RICHARD L., MEURIS G.C. S., MELISSA G.A.V. Equilibrium study of binary mixture biosorption of $\mathrm{Cr}$ (III) and $\mathrm{Zn}$ (II) by dealginated seaweed waste: investigation of adsorption mechanisms using X-ray photoelectron spectroscopy analysis. Environmental Science and Pollution Research, 26, 28470, 2019.

15. YANG X., ZHAO Z., ZHANG G., HIRAYAMA S., NGUYEN B. V., LEI Z., SHIMIZU K., ZHANG Z. Insight into $\mathrm{Cr}(\mathrm{VI})$ biosorption onto algal-bacterial granular sludge: $\mathrm{Cr}(\mathrm{VI})$ bioreduction and its intracellular accumulation in addition to the effects of environmental factors. Journal of Hazardous Materials, 414, 125479, 2021.

16. RENITTA J., PAMELA J., ANOOP K.Y., NITIN D. Biosorption and biotransformation of hexavalent chromium [Cr(VI)]: A comprehensive review, Chemosphere, 207, 255, 2018.

17. BHAWNA T., BULBUL G., INDU S.T. Biosorption of $\mathrm{Cr}$ (VI) from aqueous solution by extracellular polymeric substances (EPS) produced by Parapedobacter sp. ISTM3 strain isolated from Mawsmai cave, Meghalaya, India. Environmental Research, 191, 110064. 2020.

18. LI X., SUN Y., ZHOU L., WANG J., LI W. Removal of Low Concentration Chromium (III) from Aqueous Solution with 4 Microbial Biosorbents. Advanced Materials Research, 610-613, 1863, 2012.

19. NEWCOMBE G., DRIKAS M. Adsorption of NOM onto activated carbon: electrostatic and non-electrostatic effects. Carbon, 35, 1239, 1997.

20. ZHANG C., REN H., ZHONG C., WU D. Biosorption of $\mathrm{Cr}(\mathrm{VI})$ by immobilized waste biomass from polyglutamic acid production, Scientific Reports, 10, 3705, 2020.
21. DEBABRATA P., LALA B.S., BIBHUTI B.M., NIHARBALA D. Biosorption for removal of hexavalent chromium using microalgae Scenedesmus sp.. Journal of Cleaner Production, 209, 617, 2019.

22. NABA K.M., ANGELA S., SHAMPA D., SOUMYA C. Optimization of $\mathrm{Cr}(\mathrm{VI})$ biosorption onto Aspergillus niger using 3-level Box-Behnken design: Equilibrium, kinetic, thermodynamic and regeneration studies. Journal of Genetic Engineering and Biotechnology, 15, 151, 2017.

23. VIDHI K., CHIRAYU D. Biosorption of $\mathrm{Cr}(\mathrm{VI})$ by Halomonas sp. DK4, a halotolerant bacterium isolated from chrome electroplating sludge. Environmental Science and Pollution Research, 27, 27330, 2020.

24. LIU X., GAO C., LIANG C. Copper (II) Removed from Aqueous Solutions by Aminated Bagasse Pith, Journal of Residuals Science \& Technology, 13, 225, 2016.

25. SONG Q., YANG B., WANG H. Effective Removal of Copper (II) and Cadmium (II) by Adsorbent Prepared from Chitosan-modified Magnetic Biochar. Journal of Residuals Science \& Technology, 13, 197, 2016.

26. ROOHAN R., MORTEZA K., MASOUD T.G. Kinetic modeling and thermodynamic study to remove $\mathrm{Pb}(\mathrm{II})$, $\mathrm{Cd}(\mathrm{II}), \mathrm{Ni}(\mathrm{II})$ and $\mathrm{Zn}(\mathrm{II})$ from aqueous solution using dead and living Azolla filiculoides. Journal of Hazardous Material, B134, 120, 2006.

27. ARTI M., BULBUL G., NAVEEN K., RASHMI S., AJIT V., INDU S.T. Synthesis of calcite-based bio-composite biochar for enhanced biosorption and detoxification of chromium $\mathrm{Cr}(\mathrm{VI})$ by Zhihengliuella sp. ISTPL4. Bioresource Technology, 307, 123262, 2020.

28. NOURA E.E., AYMAN Y.E., ABEER A.G., MOHAMMED S.E., WESAMELDIN I.A.S. Innovative low-cost biosorption process of $\mathrm{Cr}^{6+}$ by Pseudomonas alcaliphila NEWG-2. Scientific Reports, 10, 14043, 2020.

29. SAADET S., OSMAN G., ERMAN S.I., NEBIL Y. Adsorption of $\mathrm{Cd}(\mathrm{II}), \mathrm{Cu}(\mathrm{II})$, and $\mathrm{Ni}(\mathrm{II})$ ions by Lemna minor L. Effect of physicochemical environment. Journal of Hazardous Materials, B126, 96, 2005.

30. ASMA A., SAMIRA A., DJAMEL N., ELHADJ M., MOHAMED T., VASILE H. Modeling biosorption of $\mathrm{Cr}(\mathrm{VI})$ onto Ulva compressa L. from aqueous solutions. Water Sci. Technol., 77, 60, 2018.

31. KIM Y., KIM J. Isotherm, kinetic and thermodynamic studies on the adsorption of paclitaxel onto Sylopute. J. Chem. Thermodynamics, 130, 104, 2019.

32. MAHFOUD B., DJAMEL N., SAMIRA A., SALAH C., ABDELHAMID M. Uranium (VI) adsorption on synthesized 4A and P1 zeolites: equilibrium, kinetic, and thermodynamic studies. Comptes Rendus Chimie, 18, 261, 2015.

33. MURPHY V., HUGHES H., MCLOUGHLIN P. Enhancement strategies for $\mathrm{Cu}(\mathrm{II}), \mathrm{Cr}(\mathrm{III})$ and $\mathrm{Cr}(\mathrm{VI})$ remediation by a variety of seaweed species. Journal of Hazardous Materials, 166, 318, 2009.

34. SHRAVAN K., TASRIN S., SELVARAJU N., PRASANNA V.R. Kinetic and thermodynamic studies on biosorption of $\mathrm{Cr}(\mathrm{VI})$ on raw and chemically modified Datura stramonium fruit. Environmental Monitoring and Assessment, 192, 248, 2020.

35. YESIM S., ISIL A., KAYA, TULIN K. Simultaneous Biosorption of Chromium (VI) and Copper (II) on Rhizopus Arrhizus in Packed Column Reactor: Application of the Competitive Freundlich Mode. Hydrometallics, 34, 3155, 1999. 
36. MANOBALA T., SHUKLA S.K., RAO T.S., KUMAR M.D. Kinetic modelling of the uranium biosorption by Deinococcus radiodurans biofilm. Chemosphere, 269, 128722, 2021.

37. SATHYA V., SINDUJA M., KALPANA P., MAHESWARI M., RAMASUBRAMANIYAN M.R., MAHIMAIRAJA S. Strategic study of adsorption and desorption of chromium on vertisols and its implication in developing an effective remediation technology. International Journal of Environmental Analytical Chemistry, 23, 1, 2021.

38. FANGZHOU LI, YAPING ZHANG, SHUI WANG, et al. Insight into ex-situ thermal desorption of soils contaminated with petroleum via carbon number-based fraction approach. Chemical Engineering Journal, 385, 123946, 2020. 